Article

\title{
Do Grazing Systems and Species Composition Affect Root Biomass and Soil Organic Matter Dynamics in Temperate Grassland Swards?
}

\author{
Martine J. J. Hoogsteen ${ }^{1,2, *}$ C , Evert-Jan Bakker ${ }^{3}$, Nick van Eekeren ${ }^{4}$, Pablo A. Tittonell ${ }^{2}$, \\ Jeroen C. J. Groot ${ }^{2} \mathbb{D}$, Martin K. van Ittersum ${ }^{5}$ and Egbert A. Lantinga ${ }^{2}$ \\ 1 National Institute for Public Health and the Environment, Antonie van Leeuwenhoeklaan 9, \\ 3721MA Bilthoven, The Netherlands \\ 2 Farming Systems Ecology Group, Wageningen University \& Research, Droevendaalsesteeg 1, \\ 6708 PB Wageningen, The Netherlands; p.a.tittonell@rug.nl (P.A.T.); jeroen.groot@wur.nl (J.C.J.G.); \\ egbert.lantinga@gmail.com (E.A.L.) \\ 3 Mathematical and Statistical methods, Wageningen University \& Research, Droevendaalsesteeg 1, \\ 6708 PB Wageningen, The Netherlands; evert-jan.bakker@wur.nl \\ 4 Louis Bolk Institute, Kosterijland 3-5, 3981 AJ Bunnik, The Netherlands; n.vaneekeren@louisbolk.nl \\ 5 Plant Production Systems Group, Wageningen University \& Research, Droevendaalsesteeg 1, \\ 6708 PB Wageningen, The Netherlands; martin.vanittersum@wur.nl \\ * Correspondence: martine.hoogsteen@rivm.nl; Tel.: +31-655-282-858
}

Received: 24 December 2019; Accepted: 3 February 2020; Published: 10 February 2020

\begin{abstract}
Elevating soil organic matter (SOM) levels through changes in grassland management may contribute to lower greenhouse gas concentrations in the atmosphere and mitigate climate change. SOM dynamics of grassland soils may be affected by grazing systems and plant species composition. We analyzed the effects of simulated grazing systems (continuous (CG), rotational (RG), and lenient strip grazing (LG)) and species composition (monocultures of perennial ryegrass fertilized (LP+) and unfertilized (LP-)), tall fescue (fertilized, FA+), and a mixture of these two species with white clover (fertilized, LFT+)) on root biomass and SOM dynamics in field experiments on loamy and sandy soils in the Netherlands. Dried cattle manure was added to all fertilized treatments. We hypothesized that SOM accumulation would be highest under CG and LG, and FA+ and LFT+ as a consequence of greater belowground biomass production. SOM was monitored after conversion from arable land for a period of two years (loamy and sandy soil) and five years (sandy soil). We found that management practices to increase SOM storage were strongly influenced by sampling depth and length of the grassland period. SOM increased significantly in nearly all fertilized treatments in the 0-60 cm layer. No differences between species compositions were found. However, when only the 30-60 cm soil layer was considered, significantly higher SOM increases were found under FA+, which is consistent with its greater root biomass than the other species. SOM increases tended to be higher under LG than RG. The results of this study suggest that it seems possible to comply with the 4-thousandth initiative during a period of five years with fertilized perennial ryegrass or tall fescue in monoculture after conversion from arable land. It remains to be investigated to which extent this sequestration of carbon can be maintained after converting grassland back to arable land.
\end{abstract}

Keywords: grassland species; sampling depth; carbon sequestration; land-use change

\section{Introduction}

Accumulation of soil organic matter (SOM) may improve soil quality by enhancing aggregate stability, soil life, crop nutrition, water infiltration, and water holding capacity. A sufficiently high 
SOM content is therefore crucial to enhance grassland productivity. Great concern exists about the effects of climate change on SOM stocks in Western Europe [1-3], as a warmer and wetter climate will enhance SOM decomposition. Over the last century, a temperature rise of $1.6^{\circ} \mathrm{C}$ has been observed and precipitation has increased by 21 percent in the Netherlands [4]. At the same time, greater risks for prolonged drought periods are foreseen [5]. To be able to cope with either sudden water shortages or large surpluses, it is of key importance for grassland-based dairy farmers to explore management options that maintain or increase SOM. Moreover, grasslands could function as potential carbon sinks when managed properly [6] and can, therefore, play an important role in the recently proposed 4-thousandth initiative [7].

SOM changes depend on the amount and chemical composition of the applied materials, as well as the rates of decomposition of both the existing and added OM. The latter is predominantly influenced by climatic and edaphic factors like soil texture, soil structure, and microbial activity [8]. Several studies have focused on the effects of climatic factors such as temperature and precipitation and of soil texture on SOM dynamics in temperate grasslands (e.g., $[3,9,10])$. Furthermore, the positive effects of increased organic matter inputs through, for instance, animal manure on SOM stocks of grasslands have received due attention [11-13]. However, data regarding the effects on SOM dynamics of other management factors such as grazing systems and plant species composition are still scarce.

Decaying plant roots and aboveground plant tissues are the main input sources of organic matter in soils of ungrazed natural grasslands $[14,15]$. Several authors have reported that the fraction of carbon (C) retained in the soil from decaying roots is greater than that from decaying shoots due to the greater lignin content of root tissues and physicochemical C protection mechanisms in the soil [16-18]. In managed grasslands, farmers are able to influence root mass and therefore SOM dynamics through grazing management $[19,20]$. In this respect, both Deinum [21] and Lantinga [22] have reported that throughout the grazing season, the root biomass of grazed swards was larger under continuous grazing as compared to rotational grazing. This was associated with a higher tiller density under continuous grazing, where the grass sward is defoliated very frequently. Moreover, Crider [23] and Ennik et al. [19] observed that infrequent grass cuttings, like under rotational grazing, led to a standstill in root production during the first few weeks of the regrowth period. In this case, carbohydrate reserves and assimilates will be used in the first instance predominantly for the re-establishment of the shoot/root ratio. Next to continuous grazing, other systems that theoretically have the potential to increase SOM through enhanced root production also include the so-called "Pure Graze" system. The "Pure Graze" system is a Dutch lenient strip grazing system that uses movable fences, and cattle are put to graze in long-standing biomass for a few hours (see the Materials and Methods section for further details). In both continuous and lenient strip grazing systems, shorter periods or absence of root growth stoppage occur due to smaller fluctuations in leaf area index than under rotational grazing [21-23].

Steinbeiss et al. [24] investigated the effects of plant species diversity on short-term changes in SOM stocks and found that a larger diversity of grassland species mitigated carbon losses in the $20-30 \mathrm{~cm}$ soil layer. They suggested (but not measured) that increases in carbon stocks were greater in more diverse swards due to differences in root distribution and root biomass between plant species. Currently, production grasslands in Western Europe are dominated by monocultures of perennial ryegrass (Lolium perenne L.) $[25,26]$ because of its suitability for grazing, high palatability for cattle, and high yield potential.

Based on their agronomic characteristics, tall fescue and white clover are the most suitable companion species for grazing purposes in a highly productive mixture with perennial ryegrass in north-western Europe. Tall fescue (Festuca arundinacea Schreb.) is a species that produces a large amount of belowground biomass, performs well under both grazing and mowing, and is drought resistant [27]. Due to its ability to fix atmospheric nitrogen, white clover (Trifolium repens L.) is considered a complementary species to perennial ryegrass and tall fescue. Its stoloniferous growth habit enables coexistence with both grass species leading to highly productive swards that are less 
dependent on external nitrogen $(\mathrm{N})$ inputs [28]. Despite its relatively low root biomass compared to grasses-leading to reduced carbon inputs from root material-the inclusion of white clover in this three-species mixture has three benefits: (i) the organic matter digestibility of both perennial ryegrass and white clover is higher compared to that of tall fescue, (ii) the risk of bloat is lower than in the case white clover mixed only with perennial ryegrass due to the higher content of less-digestible cell walls in tall fescue $[29,30]$, and (iii) white clover and tall fescue are more drought-resistant than perennial ryegrass $[31,32]$.

The objective of this study is to assess the effects of species composition and simulated cattle grazing systems, by applying different cutting frequencies and heights, on root biomass and SOM dynamics in loamy and sandy soils. We hypothesize that SOM accumulation rates would be highest under continuous and lenient strip grazing due to a more constant aboveground biomass production over time, no stand-still in root growth, and therefore, an expected higher root biomass. Furthermore, we hypothesize that the tall fescue monoculture, as well as the species mixture with perennial ryegrass, tall fescue and white clover, would lead to higher belowground biomass production and thus increased SOM accumulation rates compared to perennial ryegrass in monoculture. Treatments were investigated in grassland 2 to 5 years after conversion from arable land.

\section{Materials and Methods}

\subsection{Experimental Site, Treatments and Design}

The study was conducted on two sites, a sandy podzol and a silt loam fluvisol (FAO World Soil Classification) in Wageningen, the Netherlands. The sites were located on "De Bornse Weilanden" (clay content: $5 \%$; $51^{\circ} 59^{\prime} 34.0^{\prime \prime} \mathrm{N} 5^{\circ} 39^{\prime} 19.1^{\prime \prime} \mathrm{E}$ ) and "De Hoeveslagen" (clay content: $26 \%$; $51^{\circ} 57^{\prime} 10.4^{\prime \prime} \mathrm{N}$ $5^{\circ} 38^{\prime} 13.2^{\prime \prime}$ E). The loamy site was characterized by underground water flow to the nearby river Rhine. Before the experiment started, the sandy soil had been under arable cropping for more than 40 years and the loamy soil for about 20 years. Before that time, the loamy soil was used as a fruit orchard. The preceding crops (2005-2010) on the sandy soil were spring barley, maize, spring barley, potato, and winter wheat, and on the loamy soil, these were winter wheat, potato, winter wheat, sugar beet, and spring wheat. The sandy soil had received regular applications of cattle slurry (about $25 \mathrm{Mg} / \mathrm{ha} / \mathrm{yr}$ ) and the loamy soil had received no animal manure during the whole arable cropping period. The main soil characteristics are presented in Table 1.

Table 1. Main soil characteristics of the study sites. Average values of the $0-60 \mathrm{~cm}$ layer are presented for the granular composition. The $\mathrm{pH}$ of the $0-25 \mathrm{~cm}$ soil layer is given. Standard errors of the mean are given between brackets for the soil bulk density and initial soil organic matter content $\left(\mathrm{SOM}_{\mathrm{i}}\right.$, September 2011).

\begin{tabular}{|c|c|c|c|c|}
\hline & Sandy Soil & & Loamy Soil & \\
\hline Sand (\%) & 89 & & 15 & \\
\hline Silt (\%) & 6 & & 59 & \\
\hline Clay (\%) & 5 & & 26 & \\
\hline $\mathrm{pH}-\mathrm{CaCl}_{2}$ & 5.1 & & 7.3 & \\
\hline Soil layer & $\begin{array}{l}\text { Bulk density } \\
\left(\mathrm{g} \mathrm{cm}^{-3}\right)\end{array}$ & $\begin{array}{l}\mathrm{SOM}_{\mathrm{i}} \\
\left(\mathrm{Mg} \mathrm{ha}^{-1}\right)\end{array}$ & $\begin{array}{l}\text { Bulk density } \\
\left(\mathrm{g} \mathrm{cm}^{-3}\right)\end{array}$ & $\begin{array}{l}\mathrm{SOM}_{\mathrm{i}} \\
\left(\mathrm{Mg} \mathrm{ha}^{-1}\right)\end{array}$ \\
\hline $0-10 \mathrm{~cm}$ & $1.31(0.05)$ & $42.6(0.4)$ & $1.30(0.04)$ & $40.0(0.4)$ \\
\hline $10-30 \mathrm{~cm}$ & $1.50(0.01)$ & $79.7(0.7)$ & $1.46(0.01)$ & $72.5(1.5)$ \\
\hline $30-60 \mathrm{~cm}$ & $1.60(0.01)$ & $71.7(2.8)$ & $1.43(0.01)$ & $70.4(2.7)$ \\
\hline
\end{tabular}

The experimental fields were sown by hand in April 2011 and measurements were conducted for a period of five (sand) and two (loam) years: one year during the establishment year (April 2011-April 2012) of the sown swards and the subsequent complete growing seasons. A mixture of the diploid perennial ryegrass (Lolium perenne L.) cultivars Barflip, Barforma, and Arsenal was sown for 
the treatments LP- (unfertilized) and LP+ (fertilized). The tall fescue (Festuca arundinacea Schreb; F) cultivars Barolex and Bariane were used for the fertilized monoculture FA+. The same cultivars of both perennial ryegrass and tall fescue were used for the mixture (LFT+) with white clover (Trifolium repens L.; T) cultivars, Alice and Riesling. The unfertilized LP- treatment was included in the experiment to compare the differences in SOM changes over time with the fertilized LP+ treatment. All seeding rates are listed in the supplementary materials (Table S1).

In the year of establishment, the LP+ and FA+ treatments were fertilized with cattle manure granules (200 kg N/ha). To promote tillering, calcium ammonium nitrate (CAN; $52.5 \mathrm{~kg} \mathrm{~N} / \mathrm{ha}$ ) was applied once in late summer of 2011 to all fields, including the LP- treatment. In the subsequent years, the monocultures LP+ and FA+ were fertilized with a combination of mineral fertilizer nitrogen ( $200 \mathrm{~kg} \mathrm{~N} / \mathrm{ha}$ applied as CAN) and cattle manure granules ( $50 \mathrm{~kg} \mathrm{~N} / \mathrm{ha}$ ). The species mixture containing white clover was fertilized only with the manure granules $(50 \mathrm{~kg} \mathrm{~N} / \mathrm{ha})$. This amount of manure granules corresponds to an organic matter $(\mathrm{OM})$ input from cattle manure at a rate of ca. $2.2 \mathrm{Mg}$ $\mathrm{OM} / \mathrm{ha} /$ year. All fertilizers (manure, CAN and trace elements) were applied to the experimental plots by hand through aboveground spreading.

The $\mathrm{N}$ content of the manure was analyzed and averaged $16.6 \mathrm{~g} \mathrm{~N} / \mathrm{kg}$ air-dry matter. The OM content of the granules was $74 \%$. Swards under the continuous grazing system received five split applications of CAN, whereas those under rotational and lenient strip grazing systems received three split applications of CAN. The dates and amounts of fertilizer application are shown in the supplementary materials, Tables S2 and S3.

Three cutting regimes reflecting three different grazing systems were superimposed: rotational (RG), continuous (CG), and lenient strip (LG) grazing. Normally in practice, cattle in rotational grazing systems are put to graze when the standing biomass above $4 \mathrm{~cm}$ stubble height is about 1.5 to $2 \mathrm{Mg}$ dry matter/ha and are shifted to a new paddock every three to five days [33]. In our experiment, rotational grazing was simulated by mowing five times per year at a height of $4 \mathrm{~cm}$. Cutting took place when the sward height of the fertilized treatments was about $18 \mathrm{~cm}$ on the day of cutting. In the case of commercial cattle farms, continuous grazing is generally characterized by grazing management that aims to maintain a sward height of about $8 \mathrm{~cm}$ throughout the growing season. In our experiment, the continuous grazing system was simulated through frequent cutting (eight to nine times per year) when the sward height of the fertilized plots was about $11 \mathrm{~cm}$. The cutting height was $4 \mathrm{~cm}$ resulting in the desired average sward height of $8 \mathrm{~cm}$. In practice, the "Pure Graze" system is characterized by cows that are put to graze in swards with a relatively large amount of standing biomass (2.5-3.0 Mg $\mathrm{DM} /$ ha above $4 \mathrm{~cm}$ stubble height). Movable fences are used to enclose the grazing area of the cows and, every three to six hours, the grazing area is enlarged by moving the front fence when about half of the available biomass has been defoliated down to a sward height of about $10 \mathrm{~cm}$ [33]. Generally, the rear fence is moved only once per day. Hereafter we will refer to this system as lenient strip (LG) grazing. In our experiment, lenient strip grazing was simulated by mowing at a cutting height of $10 \mathrm{~cm}$. Herbage was harvested about seven times per year. Averages of the harvested herbage per treatment are given in the supplementary materials (Figure S2). The sward height of the fertilized plots was around $17 \mathrm{~cm}$ on the day of cutting. An overview of the cutting heights, cutting interval, and herbage heights at defoliation of the simulated grazing systems is presented in Table 2.

Table 2. Overview of the simulated grazing systems. CS = continuous grazing, LS = lenient strip grazing, and RS = rotational grazing.

\begin{tabular}{cccc}
\hline Grazing System & Cutting Height (cm) & $\begin{array}{c}\text { Average Cutting Interval in } \\
\text { 2012-2013 (Days) }\end{array}$ & $\begin{array}{c}\text { Average Grass Height at } \\
\text { Defoliation in 2013 (cm) }\end{array}$ \\
\hline Continuous (CG) & 4 & 23 & 11 \\
Lenient strip (LG) & 10 & 32 & 17 \\
Rotational (RG) & 4 & 48 & 18 \\
\hline
\end{tabular}


The experiment was laid out on both soil types in a split-plot design with four replications (blocks) with three plots each, to which the grazing systems were randomly assigned. Species composition (LP-, LP+, FA+, LFT+) was randomly assigned to the four subplots within the main plots. Hence, each of the two experiments consisted of 12 plots ( 4 blocks $\times 3$ grazing systems) and 48 subplots ( 4 species composition treatments per plot). The gross subplot size was $2.75 \times 10 \mathrm{~m}$. The net subplot size was $1.5 \times 10 \mathrm{~m}$.

Precipitation data were obtained from a weather station nearby Wageningen and temperature data were obtained from the weather station at Deelen [34]. During the experimental period (2011-2016), the mean annual temperature was $11.0^{\circ} \mathrm{C}$ and the average annual precipitation sum amounted $907 \mathrm{~mm}$. When dry spells occurred during the summer, fields were occasionally irrigated. This was only done when perennial ryegrass started yellowing and browning as a consequence of drought stress. Each time, 20-25 mm of water was applied.

\subsection{Harvesting and Processing of Samples}

\subsubsection{Biomass Samples}

The plots were cut with a Haldrup grass harvester (Haldrup, Løgstør, Denmark). In the year of establishment (2011), three cuts were taken at a cutting height of $4 \mathrm{~cm}$. In the following years, harvesting took place between May and November. A biomass subsample was taken after each cutting event and brought to the laboratory. The fresh weight was measured and samples were dried overnight at $70{ }^{\circ} \mathrm{C}$ to determine the dry matter content.

Root samples were collected down to a depth of $60 \mathrm{~cm}$ for each subplot in July 2013 and March 2014 by using a hydraulic auger. Each field was sampled twice and the 0-10, 10-30 and 30-60 cm soil layers were collected separately. The $0-10 \mathrm{~cm}$ layer was sampled because this is the depth used in the standard procedure for sampling grassland soils in the Netherlands. The 10-30 cm layer was sampled because of differences in root distribution patterns between perennial ryegrass and tall fescue: about $80 \%$ of the root biomass of perennial ryegrass occurs in the $0-8 \mathrm{~cm}$ soil layer, while only about $65 \%$ of the roots of tall fescue can be found here [35]. According to a literature review by Lorentz and Lal [36], about $95 \%$ of the total grass root biomass occurs in the $0-60 \mathrm{~cm}$ soil layer. Therefore, we also sampled the 30-60 cm soil layer. Samples were put in $10 \mathrm{~L}$ buckets with lukewarm water (1 bucket for each sampled experiment plot) and soaked for a few hours. Next, the soil cores were washed under running water. After extensive rinsing, the above-ground biomass was cut off and the roots were dried at $70{ }^{\circ} \mathrm{C}$ overnight. The dry weight was recorded.

\subsubsection{Soil Samples}

Soil sampling followed the sampling depths of $0-10,10-30$, and 30-60 $\mathrm{cm}$ for root biomass and SOM. An overview of the root and SOM sampling dates is provided in Table 3. Because the root biomass sampling took a number of days, the month is indicated in this table. The time indication for SOM is also given in the table: in the remainder of the paper, "two years" refers to the monitoring period 19 September 2011 to 27 January 2014 and "five years" refers to the period 19 September 2011 to 20 May 2016. The initial SOM content was determined in September 2011 and the second sampling took place when the cutting regimes started (May 2012). In February 2014, the soil bulk density was determined for the $0-60 \mathrm{~cm}$ profile using cylindrical cores with a diameter of $5 \mathrm{~cm}$. On both locations, a small pit was dug in six subplots (two fields per grazing regime). Cores were pressed horizontally in the soil profile, the cylinders were removed, and the moist samples were put in paper bags. Samples were dried overnight at $105^{\circ} \mathrm{C}$ and their dry weight was recorded. Details on the conversion from SOM contents to stocks are given in the supplementary materials, Box S1. 
Table 3. Soil organic matter (SOM) and root biomass sampling dates per soil type. L = loam and $\mathrm{S}=$ sand. The time indication refers to the period in which SOM dynamics were monitored.

\begin{tabular}{cccc}
\hline Date & SOM Measurement & Root Biomass Measurement & Time Indication \\
\hline $19-9-2011$ & $\mathrm{~L}+\mathrm{S}$ & \\
$22-5-2012$ & $\mathrm{~L}+\mathrm{S}$ & \\
$25-9-2012$ & $\mathrm{~L}+\mathrm{S}$ & 2 years \\
$28-1-2013$ & $\mathrm{~L}+\mathrm{S}$ & (19 September 2011 until \\
$27-5-2013$ & $\mathrm{~L}+\mathrm{S}$ & \\
$23-9-2013$ & $\mathrm{~L}+\mathrm{S}$ & \\
$27-1-2014$ & $\mathrm{~L}+\mathrm{S}$ & \\
$21-3-2016$ & $\mathrm{~S}$ & & 5 years \\
$20-5-2016$ & $\mathrm{~S}$ & & (19 September 2011 until \\
July 2013 & & $\mathrm{~L}+\mathrm{S}$ & 20 May 2016) \\
March 2014 & & $\mathrm{~L}+\mathrm{S}$ & \\
\hline
\end{tabular}

Soil and manure granule samples were analyzed for organic matter content by the loss-on-ignition (LOI) method. The LOI method was chosen above other SOM or SOC analysis procedures because of its relatively large sample weights. To be able to monitor SOM changes within a short experimental period, the analytical error had to be minimized. See Hoogsteen et al. [37] for details on the method. The ignition conditions were $550^{\circ} \mathrm{C}$ for a period of three hours. Sample weights of $20 \mathrm{~g}$ (soil) and $5 \mathrm{~g}$ (manure granules) were used. The SOM content in the 0-10 cm layer in September 2011 averaged $30.2 \mathrm{~g} \mathrm{~kg}^{-1}$ ( $\mathrm{SD}=2.2$, sand) and $28.1 \mathrm{~g} \mathrm{~kg}^{-1}(\mathrm{SD}=2.3$, loam). For the $10-30 \mathrm{~cm}$ soil layer, the average $\mathrm{SOM}$ values were $28.0 \mathrm{~g} \mathrm{~kg}^{-1}\left(\mathrm{SD}=2.0\right.$, sand) and $25.5 \mathrm{~g} \mathrm{~kg}^{-1}(\mathrm{SD}=2.0$, loam). For the 30-60 $\mathrm{cm}$ soil layer, the averages were $16.0 \mathrm{~g} \mathrm{~kg}^{-1}\left(\mathrm{SD}=4.6\right.$, sand) and $15.7 \mathrm{~g} \mathrm{~kg}^{-1}(\mathrm{SD}=4.4, \mathrm{loam})$.

\subsection{Statistical Analysis}

Data were processed with Microsoft Excel 2010 and analyzed with IBM SPSS Statistics 20.0. Differences in bulk density values between the sandy and loamy soil were analyzed with a $t$-test. Average SOM contents at the beginning of the experiment in September 2011 are presented per species composition, by a combination of soil type and soil layer. The averages are based on a mixed model with species composition as fixed factor and block and plot (nested within block) as random factors (supplementary materials, Figure S1 and Table S4).

Root biomass observations were analyzed per soil type and per soil layer using analysis of variance. In each of the six analyses, species composition, grazing system and their interaction were included as fixed factors, while block and "block $\times$ grazing system" (equivalent to plot) were used as random factors. When significant interaction effects were observed, the means for the treatments (grazing system-species composition combinations) were compared pairwise using LSD.

The SOM trends over time were estimated in 15 analyses, per soil layer $(0-10,10-30,30-60,0-30$, 0-60 cm) and per combination of soil type-monitoring period (SM levels: loam 2 years, sand 2 years, and sand 5 years). All samples were included in the analyses.

In each analysis, we used a random coefficient model that also does justice to the split-plot design. The model was as follows: SOM is a dependent variable; species composition (sps) and grazing system (ss) are fixed factors; time is a (fixed) continuous variate, with included interactions for sps-ss, time-ss and time-sps; random factors are block, plot within block, field within plot and field-time interactions. This leads to fixed slope estimates that vary with species composition and grazing system and 48 random slopes. We discuss the differences in fixed slopes between species compositions and grazing systems. 


\section{Results}

\subsection{Root Biomass}

For both soil types, root biomass decreased for consecutive soil layers for all species compositions (Figure 1). The root biomass of the $0-60 \mathrm{~cm}$ layer of LP- was, on average, $1500 \mathrm{~kg} \mathrm{ha}^{-1}$ higher on the sandy soil than on the loamy soil. For FA+, the root biomass was $1800 \mathrm{~kg} \mathrm{ha}^{-1}$ higher on the loamy soil than on the sandy soil. In the $0-10 \mathrm{~cm}$ soil layer, the effect of species composition was significant for both soil types, with the highest root biomass values for FA+, followed by LP+ (see Table 4 and supplementary materials, Table S5). Root biomass of the mixture with tall fescue (LFT+) was similar to unfertilized perennial ryegrass plots.

Table 4. Results of the analysis of variance on 288 root biomass observations. Averages of November 2013 and March 2014 were used for the analysis. Data were analysed per soil layer and per soil type. Letters in subscript " $\mathrm{s}$ " and " 1 " resemble sand and loam, respectively. Species composition and grazing system were taken as fixed factors and plot (grazing system $\times$ block) as a random factor. F- and $P$-values are given.

\begin{tabular}{lllllllll}
\hline Soil Layer $(\mathbf{c m})$ & & & $\mathbf{0 - 1 0}$ & & $\mathbf{1 0 - 3 0}$ & & 30-60 \\
\hline Sand & $\mathrm{df1}$ & $\mathrm{df2}$ & $\mathrm{F}$ & $P$ & $\mathrm{~F}$ & $P$ & $\mathrm{~F}$ & $P$ \\
\hline Intercept & 1 & 6 & 1751 & 0.00 & 792 & 0.00 & 206 & 0.00 \\
Grazing system & 2 & 6 & 1.8 & 0.25 & 0.6 & 0.59 & 0.6 & 0.59 \\
Block & 3 & 6 & 0.3 & 0.82 & 0.5 & 0.71 & 0.3 & 0.82 \\
Grazing system $\times$ Block & 6 & 27 & 0.8 & 0.61 & 1.7 & 0.16 & 2.6 & 0.04 \\
Species composition & 3 & 27 & 6.6 & 0.00 & 9.1 & 0.01 & 38 & 0.00 \\
Species composition $\times$ Grazing system & 6 & 27 & 0.8 & 0.56 & 1.9 & 0.11 & 2.5 & 0.05 \\
\hline Loam & $\mathrm{df1}$ & $\mathrm{df2}$ & $\mathrm{F}$ & $P$ & $\mathrm{~F}$ & $P$ & $\mathrm{~F}$ & $P$ \\
\hline Intercept & 1 & 6 & 1249 & 0.00 & 3199 & 0.00 & 373 & 0.00 \\
Grazing system & 2 & 6 & 4.8 & 0.06 & 1.1 & 0.40 & 2.1 & 0.21 \\
Block & 3 & 6 & 5.2 & 0.04 & 0.1 & 0.96 & 1.5 & 0.30 \\
Grazing system $\times$ Block & 6 & 27 & 0.1 & 1.00 & 2.7 & 0.03 & 0.4 & 0.86 \\
Species composition & 3 & 27 & 24 & 0.00 & 32 & 0.00 & 14 & 0.00 \\
Species composition $\times$ Grazing system & 6 & 27 & 0.7 & 0.73 & 2.0 & 0.11 & 0.3 & 0.91 \\
\hline
\end{tabular}

In the 10-30 cm soil layer, root mass of FA+ was also greater than the other species compositions and no differences in root biomass were observed between LP-, LP+, and LFT+. This was also found in the 30-60 cm soil layer of the loamy soil. Root biomass of LP-, LP+ and LFT+ was twice as large in the 30-60 cm soil layer of the loamy soil as compared to the sandy soil, whereas no effect of soil type was observed on the root biomass of FA+ (supplementary materials, Table S5). We found no significant effects of the three simulated grazing systems on root biomass in any of the soil layers (Table 4). 

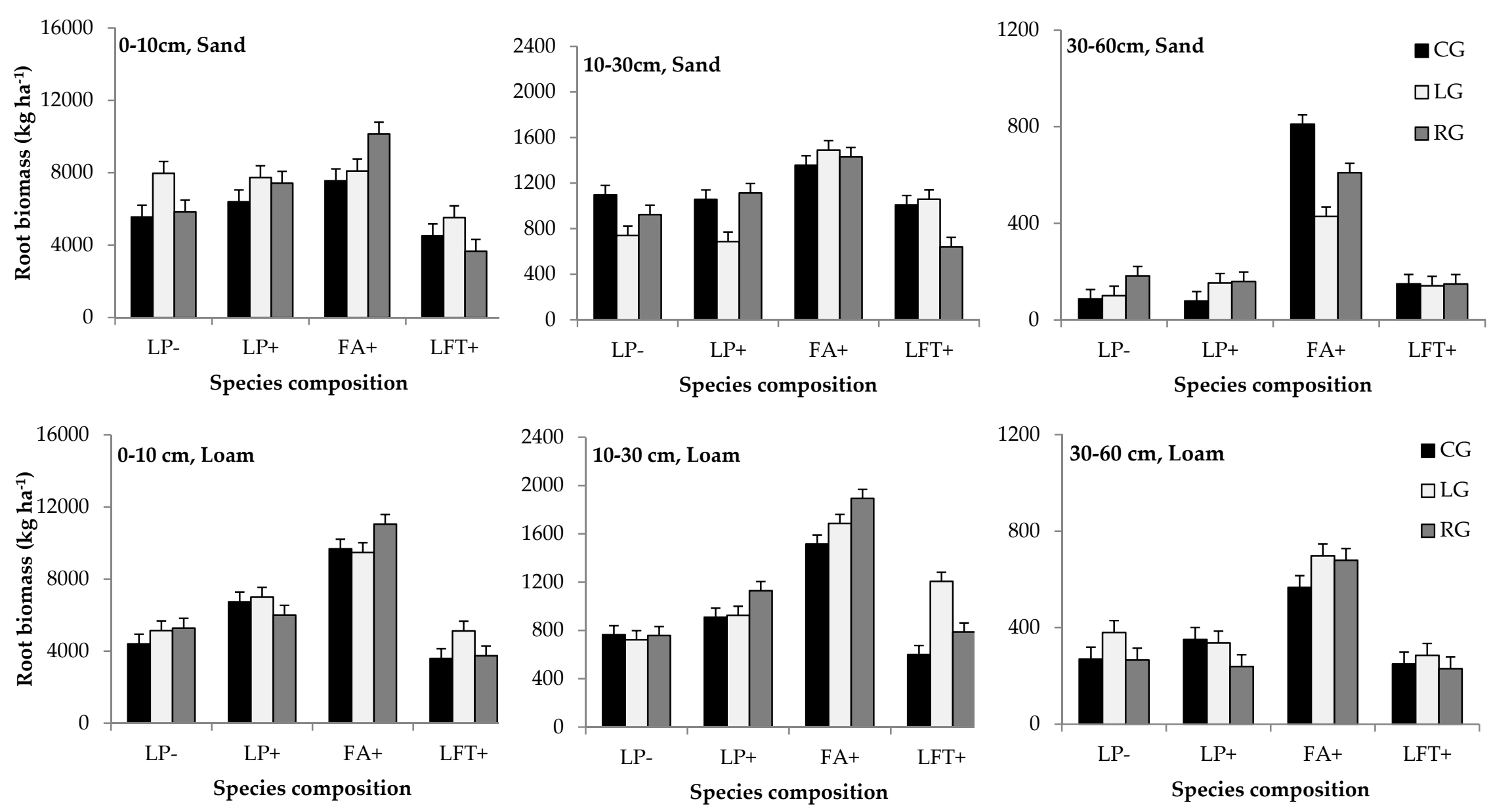

Figure 1. Average root biomass in July 2013 and March 2014 per soil layer per treatment. LP- = unfertilized perennial ryegrass. LP+ = fertilized perennial ryegrass. $\mathrm{FA}+=$ fertilized tall fescue. LFT $+=$ fertilized perennial ryegrass, tall fescue, and white clover. Simulated grazing systems: CG $=$ continuous grazing, LG $=$ lenient strip grazing, and RG = rotational grazing. Standard errors of the mean are given for each soil type-soil layer combination. 


\subsection{Soil Organic Matter Dynamics}

During the first two years of the experiment, SOM increased significantly over time in the 0-10 cm soil layer in all fertilized treatments (Figure 2a,b), and the differences between the LP+, FA+, and LFT+ treatments were not significant (supplementary materials, Table S6). After two years, the average increase in SOM was $1.9 \mathrm{Mg} \mathrm{ha}^{-1} \mathrm{yr}^{-1}$ in the sandy soil and $2.2 \mathrm{Mg} \mathrm{ha}^{-1} \mathrm{yr}^{-1}$ in the loamy soil, while for unfertilized treatments, these accumulation rates were 0.6 (sand) and $0.9 \mathrm{Mg} \mathrm{ha}^{-1} \mathrm{yr}^{-1}$ (loam).
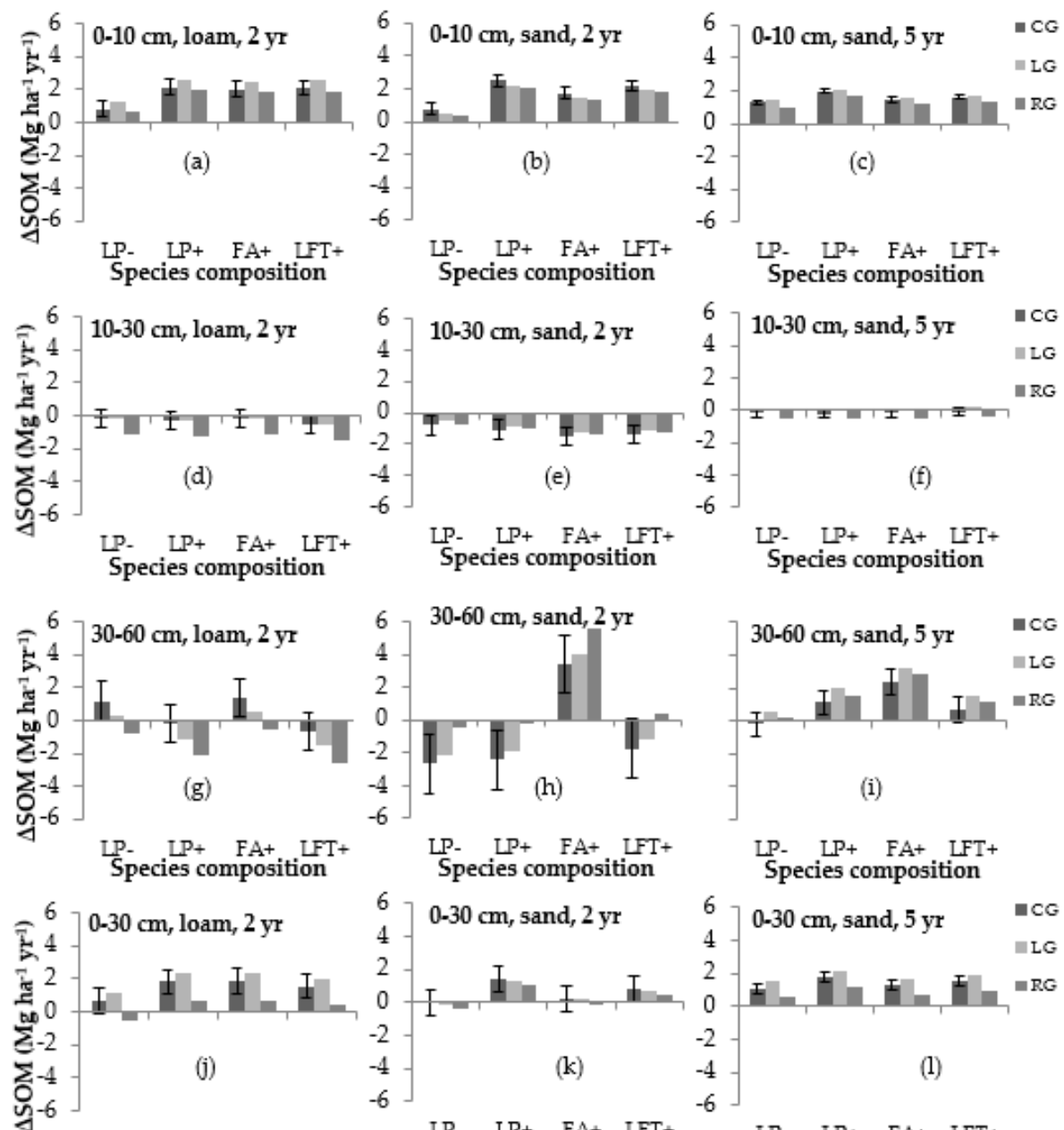

LP.
Species composition

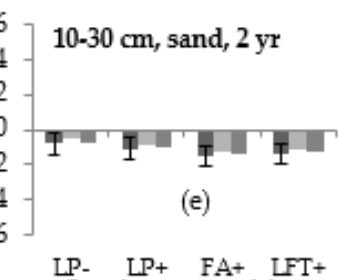

$\mathrm{LP}$ - $\mathrm{LP}+\underset{\mathrm{FA}+}{\mathrm{LFT}+}$
Species composition

LP. LP+ FA+ LFT+

Species composition
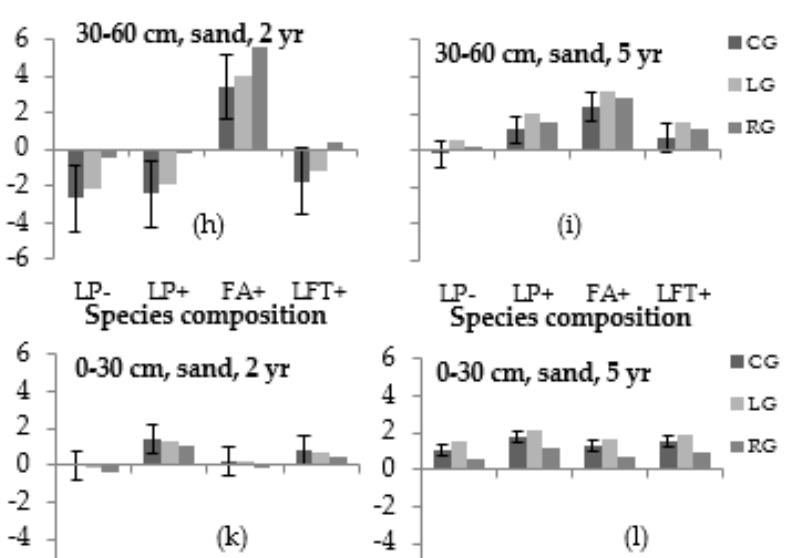

(k)
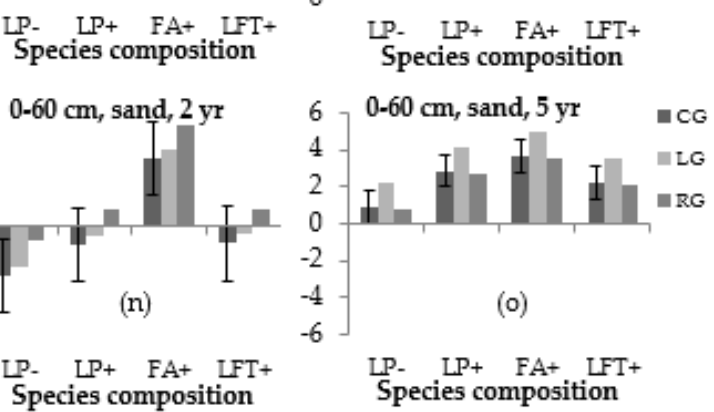

Figure 2. Average rates of change of soil organic matter $(\triangle \mathrm{SOM})$ in $\mathrm{Mg} \mathrm{ha}^{-1} \mathrm{yr}^{-1}$ per soil layer per treatment for the period September 2011 to January 2014 (sand and loam, 2 years) and the period September 2011 to May 2016 (sand, 5 years). LP- = unfertilized perennial ryegrass. LP+ = fertilized perennial ryegrass. FA $+=$ fertilized tall fescue. $\mathrm{LFT}+=$ fertilized perennial ryegrass, tall fescue, and white clover. Simulated grazing systems: CG = continuous grazing, LG = lenient strip grazing, and RG $=$ rotational grazing. All results of the analysis of variances on SOM dynamics underlying the results of Figure 2 are given in the supplementary materials, Table S7. Standard errors of means are provided in the first treatment and apply to all grazing-species combinations. 
In the 10-30 cm soil layer, SOM tended to decrease (five times significantly; Figure $2 \mathrm{~d}$,e). In the $30-60 \mathrm{~cm}$ soil layer, increases were observed, as well as decreases; in both cases, a significant slope was found only once (Figure 2g,h). At both experimental sites, large differences in initial SOM content of the 30-60 cm soil layer were observed between subplots: in the sandy soil, the SOM stocks ranged from 34 to $112 \mathrm{Mg} \mathrm{ha}^{-1}$ and, in the loamy soil SOM, stocks ranged from 31 to $104 \mathrm{Mg} \mathrm{ha}^{-1}$. No significant correlation was observed between initial SOM stocks and SOM rates of change (Figure S3).

In the 0-30 cm layer, SOM tended to increase for both soil types (once significantly, Figure $2 \mathrm{j}, \mathrm{k}$ ). In the 0-60 cm layer, all estimated trends were not significant except for FA+ under continuous grazing on the sandy soil (Figure 2m,n).

The experimental period of five years on the sandy soil showed significant increases in SOM in all treatments in the $0-10 \mathrm{~cm}$ soil layer (Figure $2 \mathrm{c}$ ). In the $10-30 \mathrm{~cm}$ soil layer, SOM did not significantly change except for two treatments where a significant decrease was found (Figure 2f). In the 30-60 cm soil layer, SOM increased in most of the fertilized treatments (three times significantly; Figure 2i). In the 0-30 cm soil layer, SOM increased significantly in all fertilized treatments except one (Figure 21). In the $0-60 \mathrm{~cm}$ soil layer, all estimated trends were positive and significant for six of the nine fertilized treatments (Figure 2o).

After two years, no significant effect of the grazing system was observed for any soil type-layer combination, except for the 0-30 cm layer of the loamy soil. SOM increases were significantly higher under lenient strip grazing as compared to rotational grazing $\left(\Delta \mathrm{SOM}_{\mathrm{LG}}-\Delta \mathrm{SOM}_{\mathrm{RG}}=1.61 \mathrm{Mg} \mathrm{ha}^{-1} \mathrm{yr}^{-1}, P=\right.$ 0.03 , Figure 2j; supplementary materials, Table S8). This was also observed on the sandy soil in the $0-30 \mathrm{~cm}$ layer after five years $\left(\Delta \mathrm{SOM}_{\mathrm{LG}}-\Delta \mathrm{SOM}_{\mathrm{RG}}=0.38 \mathrm{Mg} \mathrm{ha}^{-1} \mathrm{yr}^{-1}, P=0.01\right.$, Figure 21; supplementary materials, Table S8). For all soil type-layer combinations, SOM increases tended to be higher under LG than under RG. As root biomass was not significantly different for grazing systems, this increase in SOM might be attributed to greater organic matter inputs from decaying aboveground plant material. Visual observations showed that the amount of above-ground stubble was much larger under LG as compared to the other treatments ( $10 \mathrm{vs.} 4 \mathrm{~cm}$ ), resulting in a larger OM supply to the soil (data not shown).

No consistent effect of species composition was found on SOM changes over time. In the $0-10 \mathrm{~cm}$ soil layers of the loamy and sandy soil, SOM rates of change were significantly lower for LP- than for all other species compositions after a two-year period. After a five-year period, SOM increases under LP+ were significantly larger than all other species compositions in the $0-10 \mathrm{~cm}$ layer of the sandy soil. After a two and five-year period, SOM increases for FA+ tended to be higher (in some cases significantly) compared to all other species compositions in the 30-60 cm soil layer of the sandy soil (supplementary materials, Tables S6 and S9).

In the 0-30 cm soil layer, no significant differences in SOM dynamics between species compositions were found after two and five years. However, in the 0-60 cm soil layer, SOM increases tended to be higher under FA+ than under the other species compositions on sand. After a period of five years, on sand, both LP+ and FA+ showed significantly higher SOM increases than LP- in the $0-60 \mathrm{~cm}$ soil layer. The estimated differences were 1.96 and $2.77 \mathrm{Mg} \mathrm{ha}^{-1} \mathrm{yr}^{-1}$, respectively. The difference in estimated SOM trends between sand and loam, both averaged over the 12 treatments, was not significant for any of the layers $(0-10,10-30,30-60,0-30,0-60 \mathrm{~cm})$.

No correlation was detected between SOM rates of change and root biomass values, as shown in Figure S4 (supplementary materials), in which only the results of the $0-30 \mathrm{~cm}$ soil layer are presented due to the large variation of the initial SOM content in the 30-60 cm layer (cf. supplementary materials, Figure S3).

\section{Discussion}

\subsection{Effects of Grazing Systems on Root Biomass and SOM Dynamics}

During the first two years of this field experiment on sandy and loamy soils, we found no significant effects of the three simulated grazing systems on root biomass for any of the soil layers 
(Table 4). In the light of these findings, we would have to reject our hypothesis that SOM accumulation rates would be highest under lenient strip grazing due to an increased root biomass production. Yet, after five years, $\mathrm{SOM}$ increases tended to be higher under lenient grazing than under rotational grazing (Table S10; LG: $3.7 \mathrm{Mg} \mathrm{SOM} \mathrm{ha}^{-1} \mathrm{yr}^{-1}$ vs. RG: $2.6 \mathrm{Mg} \mathrm{ha}^{-1} \mathrm{yr}^{-1}$ ) which could be ascribed to greater OM inputs from aboveground plant residues due to the higher stubble height.

\subsection{Effects of Species Composition and Fertilization on Root Biomass and SOM Dynamics}

We expected that the monoculture of and the mixtures with tall fescue (FA+, LFT+) would have a higher belowground biomass production and hence higher SOM accumulation rates as compared to perennial ryegrass in monoculture. However, the effect of species composition on root biomass was only significant in the FA+ treatments, which had the greatest root biomass in all soil layers (Figure 1, Table 4). This corroborates with Van Eekeren et al. [38] and Cougnon et al. [32], who also found greater root biomass for monocultures of tall fescue as compared to perennial ryegrass in sandy and loamy soils. The greater root biomass observed under tall fescue than for other species compositions was reflected in higher SOM accumulation rates in the sandy soil in the 30-60 cm soil layer (Figure 2h,i). This is in agreement with Carter and Gregorich [39], who also found significant increases in SOM under tall fescue after a period of seven years in the 40-60 cm soil layer of sandy loam soil. In that particular experiment, SOM stocks increased by about $5 \mathrm{Mg} \mathrm{ha}^{-1} \mathrm{yr}^{-1}$ in the $40-60 \mathrm{~cm}$ soil layer during the first five experimental years, which is similar to our results ( $4.3 \mathrm{Mg} \mathrm{SOM} \mathrm{ha}^{-1} \mathrm{yr}^{-1}$, Figure 2i).

In the loamy soil, we did not observe significantly larger SOM increases under FA+ as compared to the other species compositions (Figure $2 \mathrm{~g}, \mathrm{~m}$ ). The difference in SOM accumulation rates under FA+ between sand and loam for the 30-60 $\mathrm{cm}$ soil layer might have been caused by the significantly lower bulk density of the loamy soil in the 30-60 cm soil layer compared to the sandy soil (Table 1, $P=0.000$ ). For this reason and the higher soil $\mathrm{pH}$, root dry matter decomposition could have been faster in the loamy soil, leading to less SOM accumulation as compared to the more compacted and less alkaline sandy soil [40]. Due to the relatively short duration of the experiment on the loamy soil, we cannot predict how SOM dynamics would evolve over time. A ley period of 3 years, which is common in the Netherlands, where often a 3-year grassland phase is followed by one or two year(s) of maize, does not seem to be long enough to detect significant increases in SOM on loamy soils.

During the entire experimental period, 2.2 $\mathrm{Mg} \mathrm{OM} \mathrm{ha}^{-1}$ was applied each year with manure granules to the fertilized treatments.

In the $10-30 \mathrm{~cm}$ layer, we found a decline of SOM in all treatments during the first two years. This is most likely a consequence of a reduction in OM input in this layer after the conversion from arable land to grassland. During the arable period, relatively large amounts of OM were added each year as crop residues. In the 10-30 cm layer of the grassland soils in our experiment, roots were the main source of $\mathrm{OM}$ and this input source was apparently not able to compensate the previous input of crop residues which were incorporated annually through ploughing. This phenomenon was also observed by Don et al. [41], who investigated the effect of the conversion from cropland to grassland on SOC stocks. They also found that SOC increased in the $0-10 \mathrm{~cm}$ soil layer and decreased in the $10-30 \mathrm{~cm}$ soil layer.

Over a period of five years, SOM had not changed in the 10-30 cm soil layer (Figure 2f). Hence, after the initial decline, SOM started increasing again two years after the conversion from arable land to grassland. This implies that both sampling depth and the length of the monitoring period are of great influence on conclusions regarding the carbon storage potential of grassland soils, especially for fields under temperate grasslands.

\subsection{Temporary Grasslands as Potential Carbon Sinks?}

Our results suggest that the conversion from arable land to temporary grassland without the application of animal manure need not necessarily lead to increased carbon stock in the soil (c.f. [6,42,43]). After a period of five years, SOM increased by $1.3 \mathrm{Mg} \mathrm{ha}^{-1} \mathrm{yr}^{-1}$ under the LP-treatment $(0-60 \mathrm{~cm}$ soil 
layer, Figure 2o), but this difference was not significantly different from zero. Under the LP+ treatment, SOM increased by $3.2 \mathrm{Mg} \mathrm{ha}^{-1} \mathrm{yr}^{-1}\left(0-60 \mathrm{~cm}\right.$ soil layer). The difference of $1.9 \mathrm{Mg} \mathrm{ha}^{-1} \mathrm{yr}^{-1} \mathrm{can}$ be attributed to the greater root biomass $\left(0.8 \mathrm{Mg} \mathrm{ha}^{-1}\right.$, root mass ${ }_{\mathrm{LP}-}-$ root mass $\left.{ }_{\mathrm{LP}+}=8.3-7.5=0.8\right)$ and the input of manure granules $\left(2.2 \mathrm{Mg} \mathrm{ha}^{-1} \mathrm{yr}^{-1}\right)$. In fields under FA+, the joint effect of manure application and increased root biomass could also be observed $\left(\Delta \mathrm{SOM}_{\mathrm{FA}+}=4 \mathrm{Mg} \mathrm{ha}^{-1} \mathrm{yr}^{-1}\right.$; Figure 2o) when considering the whole sampled profile. This indicates that there was an extra amount of around $0.8 \mathrm{Mg} \mathrm{OM} \mathrm{ha}^{-1}\left(\Delta \mathrm{SOM}_{\mathrm{FA}+}-\Delta \mathrm{SOM}_{\mathrm{LP}+}=4-3.2=0.8 \mathrm{Mg} \mathrm{ha}^{-1} \mathrm{yr}^{-1}\right)$ coming from tall fescue roots compared to the $\mathrm{LP}+$ treatment. This is equal to about one-third of the additional root biomass of tall fescue (root masses of LP+ and FA+ were, respectively, 8.3 and $10.6 \mathrm{Mg} \mathrm{ha}^{-1}$ for the $0-60 \mathrm{~cm}$ soil layer; $0.8 /(10.6$ - 8.3), (supplementary materials, Table S5).

After a period of five years, large differences in SOM accumulation rates were found between the 0-30 and 0-60 cm soil layers (Figure 21,o). Largest rates of increase were observed in the 30-60 cm soil layer (up to $70 \%$ of the total accumulation of SOM was found in this layer; for instance, for FA+, $\Delta \mathrm{SOM}_{0-30 \mathrm{~cm}}=1.2$ and $\left.\Delta \mathrm{SOM}_{0-60 \mathrm{~cm}}=4.0 \mathrm{Mg} \mathrm{ha}^{-1} \mathrm{yr}^{-1}\right)$. The divergence between the distribution of root mass and SOM was also observed by Gill et al. [40], who attributed this to differences in water availability (increased decomposition in the topsoil) and root senescence, i.e., roots in deeper soil layers persisted much longer than roots in the surface. Moreover, it seems that also a process of vertical translocation of OM had occurred from the $0-30 \mathrm{~cm}$ to the $30-60 \mathrm{~cm}$ soil layer. The mechanisms behind this cannot, however, be derived from the data gathered in this experiment; pulse labeling of plants could possibly reveal the magnitude of these processes.

Generally, the conversion from arable land to grassland is thought to lead to soil C accumulation $[44,45]$. However, this experiment has shown that conclusions on the SOM storage capacity are strongly determined by sampling depth, length of the grassland period, species composition, and management. After five years, significant increases in SOM were found for both fertilized and unfertilized treatments in the $0-10 \mathrm{~cm}$ soil layer. However, when the whole sampled profile is considered, only the fertilized treatments showed significant increases in SOM (Figure 2o). The current sampling depth in the Netherlands is $10 \mathrm{~cm}$ for grassland soils. Thus, in light of these findings, we plead to increase the sampling depth of Dutch grassland soils from 10 to $30 \mathrm{~cm}$ or, even better, to $60 \mathrm{~cm} \mathrm{[46].}$

\subsection{Comparison of the Experiment with on-Farm Grasslands}

The 0-30 cm layer of both soils in this experiment had an SOM content of about $2.8 \%$ at the start of the experiment, which is in the range of the average SOM contents of Dutch arable land on sandy and clayey soils. Reijneveld et al. [3] reported values of $2.6 \%$ and $3.4 \%$ for sand and clay, respectively. A limitation of the study is that we did not account for differences between grazing systems in grazing residues, trampling and compaction, and spatial distribution of urine and feces occurring in grazed grasslands. We can therefore only conclude as to the effects of differences between grazing systems in terms of cutting height and frequency on root biomass and SOM. Furthermore, excreta deposition of grazing animals was simulated by applying pelleted cattle manure. The manure application rate in this experiment was lower than on Dutch dairy farms, which are registered for the derogation, equivalent to $3.9 \mathrm{Mg} \mathrm{OM} \mathrm{ha}{ }^{-1} \mathrm{yr}^{-1}$ on temporary grasslands, (average $\mathrm{N}$ animal manure application rates on Dutch dairy farms registered for derogation in 2014 were 248 and $186 \mathrm{~kg} \mathrm{~N} \mathrm{ha}^{-1}$ for grassland and arable land, respectively. Temporary grasslands are considered as arable land and are under grassland for a period of less than 5 years. National fixed rate values for cattle slurry were used to convert $\mathrm{N}$ animal manure application rates into organic matter. The median of the $\mathrm{N}$ and $\mathrm{OM}$ contents of cattle slurry were $4.1 \mathrm{~g} \mathrm{~N}$ and $64 \mathrm{~g}$ OM per ton of fresh product. Thus, OM-slurry application rate on temporary grassland was, in 2014, on average $\left.248 / 4.1^{*} 64 / 10^{3}=3.9 \mathrm{Mg} \mathrm{ha}^{-1} \mathrm{yr}^{-1}\right)$, [47,48]. For this reason, higher changes in $\mathrm{OM}$ can be expected in newly sown temporary grasslands (with predominantly perennial ryegrass) on dairy farms in clayey and sandy regions of the Netherlands, especially since on dairy farms, more grazing and harvesting losses occur compared to a simulated grazing experiment. 
To comply with the recently proposed 4-thousandth initiative [7], Dutch temporary grasslands on mineral soils would have to sequester on average $0.7 \mathrm{Mg} \mathrm{SOM} \mathrm{ha}^{-1} \mathrm{yr}^{-1}$ (after Conijn and Lesschen [49]; the average SOC content of mineral soils in the Netherlands is $94 \mathrm{Mg} \mathrm{SOC} \mathrm{ha}^{-1}$ in the $0-30 \mathrm{~cm}$ soil layer; using a conversion factor of $2 \times \mathrm{SOC}=\mathrm{SOM}$, this results in $187 \mathrm{Mg} \mathrm{SOM} \mathrm{ha}^{-1}$ and $187 \times 0.004=$ $0.7 \mathrm{Mg} \mathrm{SOM} \mathrm{ha}{ }^{-1} \mathrm{yr}^{-1}$ ). Especially, the subsoil should be considered as a potential carbon sink because this layer is usually not ploughed during the arable phase of soils that are under lay-arable rotations and $C$ stocks are relatively stable. The results of this study suggest that it seems possible to comply with the 4-thousandth initiative in a period of five years after conversion from arable land to grassland, with fertilized perennial ryegrass or tall fescue in monoculture as average SOM sequestration rates were 1.5 and $2.8 \mathrm{Mg} \mathrm{ha}^{-1} \mathrm{yr}^{-1}$ in the $30-60 \mathrm{~cm}$ soil layer (cf. Figure 2i). For this reason, we highly recommend monitoring the subsoil for future carbon inventories $[46,50]$.

\section{Conclusions}

The analysis of root biomass and SOM dynamics down to $60 \mathrm{~cm}$ depth in a two-year and five-year field experiment on arable land converted to grassland, testing different sward species compositions and simulated grazing systems leads to the following conclusions:

- No effects of different simulated grazing systems in terms of cutting height and frequency on root biomass were observed in both the sandy and loamy soils during the first two years of the experiment.

- Root biomass was greatest under monocultures of tall fescue, which was also reflected in the largest SOM accumulation rates in the $30-60 \mathrm{~cm}$ soil layer of the sandy soil.

- SOM increases tended to be higher (in some cases significantly) under lenient strip grazing than under rotational grazing, most likely due to a larger input of aboveground plant residues.

- No consistent effects of species composition were found across different soil layers, except for tall fescue in dry sandy subsoils.

- No causal relationships could be established between root biomass and SOM rates of change in both soils (0-30 cm soil layer) during the first two years, probably as a consequence of declining SOM stocks in the $10-30 \mathrm{~cm}$ soil layer and large variation in both root biomass and initial SOM stocks.

- Fertilization appeared to be crucial to increase SOM stocks. In this particular experiment with simulated grazing systems, the conversion from arable land to grassland did only lead to an increase in SOM after five years (sandy soil) in the treatments with fertilization and considering the $0-60 \mathrm{~cm}$ soil profile.

With fertilized perennial ryegrass or tall fescue in monoculture, it seems possible to comply with the 4-thousandth initiative in a period of five years after conversion from arable land, but this requires that the commonly-used sampling depth of $10 \mathrm{~cm}$ for grassland soils in the Netherlands should be increased to a depth of preferably $60 \mathrm{~cm}$ to monitor soil organic matter changes. It remains to be investigated to what extent this sequestration of carbon can be maintained after converting grassland back to arable land.

Supplementary Materials: The following are available online at http:/www.mdpi.com/2071-1050/12/3/1260/s1, Figure S1: Initial soil organic matter (SOM) content $\left(\mathrm{Mg} \mathrm{ha}^{-1}\right)$ in September 2011 per species composition per soil type (sand and loam) and soil layer $(0-10 \mathrm{~cm}$ and $10-30 \mathrm{~cm}$ ); Figure S2: Harvested herbage per treatment; Figure S3: Relationship between initial soil organic matter (SOM) stocks and $\triangle \mathrm{SOM}\left(\mathrm{Mg} \mathrm{ha}^{-1} \mathrm{yr}^{-1}\right)$ per species composition for the 30-60 cm soil layer; Figure S4: Relationship between root biomass and rates of change of soil organic matter (SOM) per soil type for the $0-30 \mathrm{~cm}$ soil layer; Table S1: Seeding rates of plant species per treatment; Table S2: Dates of fertilizer application during the first two experimental years; Table S3: Annual application rates of micronutrients from 2013 to 2016; Table S4: Results of the analysis of variance on 288 SOM (soil organic matter) observations; Table S5: Average root biomass (kg dry matter/ha) in July 2013 and March 2014 per soil layer per treatment; Table S6: Estimates and P-values for differences between species compositions between SOM rates of change in $\mathrm{Mg} \mathrm{ha}^{-1} \mathrm{yr}^{-1}$ after a period of 2 years, by soil layer and by soil type; Table S7: Results of the analysis of variance on soil organic matter observations; Table S8: Estimates and P-values for differences between 
grazing systems in SOM rates of change in $\mathrm{Mg} \mathrm{ha}^{-1} \mathrm{yr}^{-1}$ in the loamy (italics) and sandy soil (bold) for the 0-30 $\mathrm{cm}$ soil layer after a period of two and five years, respectively; Table S9: Estimates for differences between species compositions in SOM rates of change in $\mathrm{Mg} \mathrm{ha}^{-1} \mathrm{yr}^{-1}$ in the sandy soil after a period of five years; Table S10: Average rates of change of soil organic matter (SOM) in $\mathrm{Mg} \mathrm{ha}^{-1} \mathrm{yr}^{-1}$ per soil layer per simulated grazing system for the period September 2011-January 2014 (sand and loam, 2 years) and the period September 2011-May 2016 (sand, 5 years); Box S1: Soil bulk density measurements and the conversion from SOM concentrations to stocks.

Author Contributions: Conceptualization, E.A.L. and M.J.J.H.; Formal analysis, M.J.J.H., E.-J.B.; Funding acquisition, E.A.L. and M.J.J.H.; Investigation, M.J.J.H.; Methodology, E.A.L. and M.J.J.H.; Writing-original draft, M.J.J.H. and E.-J.B.; Writing-review \& editing, N.v.E., M.K.v.I., J.C.J.G. and P.A.T. All authors have read and agreed to the published version of the manuscript.

Funding: This research was funded by Barenbrug Holland, the Dutch Dairy Board (In Dutch: Productschap Zuivel) and Culterra.

Acknowledgments: We wish to express our gratitude to Frans Bakker (WUR, Unifarm) for his assistance during the field work. All authors have read and agreed to the published version of the manuscript.

Conflicts of Interest: The authors declare no conflict of interest.

\section{References}

1. Bellamy, P.H.; Loveland, P.J.; Bradley, R.I.; Lark, R.; Kirk, J.D. Carbon losses from all soils across England and Wales 1978-2000. Nature 2005, 437, 245-248. [CrossRef] [PubMed]

2. Sleutel, S.; De Neve, S.; Hofman, G. Assessing causes of recent organic carbon losses from cropland soils by means of regional-scaled input balances for the case of Flanders (Belgium). Nutr. Cycl. Agroecosystems 2007, 78, 265-278. [CrossRef]

3. Reijneveld, J.A.; Van Wensum, J.; Oenema, O. Trends in soil organic carbon content of agricultural land in the Netherlands between 1984 and 2004. Geoderma 2009, 152, 231-238. [CrossRef]

4. Royal Dutch Weather Institute. Climate Observations, Hourly Weather data of The Netherlands. 2012. Available online: http://www.knmi.nl/klimatologie/uurgegevens/ (accessed on 30 November 2012).

5. Lenderink, G.; Mok, H.Y.; Lee, T.C.; Van Oldenborgh, G.J. Scaling and trends of hourly precipitation extremes in two different climate zones-Hong Kong and The Netherlands. Hydrol. Earth Syst. Sci. 2011, 15, 3033-3041. [CrossRef]

6. Smith, P. Do grasslands act as a perpetual sink for carbon? Glob. Chang. Biol. 2014, 20, 2708-2711. [CrossRef]

7. United Nations Framework Convention on Climate Change (UNFCCC). Join the $4 \%$ Initiative: Soils for food Security and Climate. 2016. Available online: Newsroom.unfccc.int/media/408539/4-per-1000-initiative.pdf. (accessed on 29 December 2016).

8. Stevenson, F.J. Humus Chemistry: Genesis, Composition, Reactions, 2nd ed.; John Wiley \& Sons: New York, NY, USA, 1994; pp. 1-23.

9. Hanegraaf, M.C.; Hoffland, E.; Kuikman, P.J.; Brussaard, L. Trends in soil organic matter contents in Dutch grasslands and maize fields on sandy soils. Eur. J. Soil Sci. 2009, 60, 213-222. [CrossRef]

10. Hopkins, D.W.; Waite, I.S.; Mc Nicol, J.W.; Poulton, P.R.; Macdonald, A.J.; O'Donnell, A.G. Soil organic carbon contents in long-term experimental grassland plots in the UK (Palace Leas and Park Grass) have not changed consistently in recent decades. Glob. Chang. Biol. 2009, 15, 1739-1754. [CrossRef]

11. Van Eekeren, N.; Boer, H.; Bloem, J.; Schouten, T.; Rutgers, M.; De Goede, R.G.M.; Brussaard, L. Soil biological quality of grassland fertilized with adjusted cattle manure slurries in comparison with organic and inorganic fertilizers. Biol. Fertil. Soils 2009, 45, 595-608. [CrossRef]

12. Maillard, É.; Angers, D.A. Animal manure application and soil organic carbon stocks: A meta-analysis. Glob. Chang. Biol. 2014, 20, 666-679. [CrossRef]

13. Verloop, J.; Hilhorst, G.J.; Pronk, A.A.; Šebek, L.B.; Van Keulen, H.; Janssen, B.H.; Van Ittersum, M.K. Organic matter dynamics in an intensive dairy production system on a Dutch Spodosol. Geoderma 2015, 237, 159-167. [CrossRef]

14. Whitehead, D.C.; Bristow, A.W.; Lockyer, D.R. Organic matter and nitrogen in the unharvested fractions of grass swards in relation to the potential for nitrate leaching after ploughing. Plant Soil 1990, 123, 39-49. [CrossRef] 
15. Dormaar, J.F. Decomposition as a process in natural grasslands. In Natural Grasslands Introduction and Western Hemisphere; Coupland, R.T., Ed.; Ecosystems of the world 8a; Elsevier: Amsterdam, The Netherlands, 1992; pp. 121-136.

16. Janssen, B.H. Organic Matter and Soil Fertility; J100-225; Wageningen Agricultural University: Wageningen, The Netherlands, 2002; p. 248.

17. Rasse, D.P.; Rumpel, C.; Dignac, M.F. Is soil carbon mostly root carbon? Mechanisms for a specific stabilisation. Plant Soil 2005, 269, 341-356. [CrossRef]

18. Schmidt, M.W.; Torn, M.S.; Abiven, S.; Dittmar, T.; Guggenberger, G.; Janssens, I.A.; Kleber, M.; Kögel-Knabner, I.; Lehmann, J.; Manning, D.A.C.; et al. Persistence of soil organic matter as an ecosystem property. Nature 2011, 478, 49-56. [CrossRef] [PubMed]

19. Ennik, G.C.; Gillet, M.; Sibma, L. Effect of high nitrogen supply on sward deterioration and root mass. In The Role of Nitrogen in Intensive Grassland Production; Prins, W.H., Arnold, G.H., Eds.; Institute for soil fertility: Haren, The Netherlands, 1980; pp. 67-76.

20. Reeder, J.D.; Franks, C.D.; Milchunas, D.G. Root biomass and microbial processes. In The Potential of U.S. Grazing Lands to Sequester Carbon and Mitigate the Greenhouse Effect; Follet, R.F., Kimble, J.M., Lal, R., Eds.; CRC Press: Boca Raton, LA, USA, 2001; pp. 163-190.

21. Deinum, B. Root mass of grass swards in different grazing systems. Neth. J. Agric. Sci. 1985, 33, 377-384.

22. Lantinga, E.A. Productivity of Grasslands under Continuous and Rotational Grazing. Ph.D. Thesis, Wageningen Agricultural University, Wageningen, The Netherlands, 1985; p. 111.

23. Crider, F.J. Root-Growth Stoppage Resulting for Defoliation of Grass; USDA Tech. Bull. No. 1102; US Department of Agriculture: Washington, DC, USA, 1955. Available online: http://books.google.nl/books?hl=nl\&lr=\&id= HLIXAAAAYAAJ\&oi=fnd\&pg=PA3\&dq=Root-growth+stoppage+resulting + for + defoliation + of + grass \& ots=I9JN11fx9A\&sig=0WFR11gMs5OC6_AAooxxrjPzbr8\#v=onepage\&q=Root-growth\%20stoppage\% 20resulting\%20for\%20defoliation\%20of\%20grass\&f=false (accessed on 27 November 2014).

24. Steinbeiss, S.; Beßler, H.; Engels, C.; Temperton, V.M.; Buchmann, N.; Roscher, C.; Kreutziger, Y.; Baade, J.; Habekost, M.; Gleixner, G. Plant diversity positively affects short-term soil carbon storage in experimental grasslands. Glob. Chang. Biol. 2008, 14, 2937-2949. [CrossRef]

25. Isselstein, J.; Jeangros, B.; Pavlu, V. Agronomic aspects of biodiversity targeted management of temperate grasslands in Europe: A review. Agron. Res. 2005, 3, 139-151.

26. De Wit, J.; Van Eekeren, N.; Wagenaar, J.; Smeding, F.W. Diverse grassland mixtures for higher yields and more stable sward quality. In Proceedings of the 17th Symposium of the European Grassland Federation, Akureyri, Iceland, 23-26 June 2013; Available online: http://www.louisbolk.org/downloads/2791.pdf (accessed on 26 November 2014).

27. Cougnon, M.; Baert, J.; Van Waes, C.; Reheul, D. Performance and quality of tall fescue (Festuca arundinacea Schreb.) and perennial ryegrass (Lolium perenne L.) and mixtures of both species grown with or without white clover (Trifolium repens L.) under cutting management. Grass Forage Sci. 2014, 69, 666-677. [CrossRef]

28. Lüscher, A.; Mueller-Harvey, I.; Soussana, J.F.; Rees, R.M.; Peyraud, J.L. Potential of legume-based grassland-livestock systems in Europe: A review. Grass Forage Sci. 2014, 69, 206-228. [CrossRef]

29. Carruthers, V.R.; Henderson, H.V. Grazing management and pasture composition on paired farms which differed in the incidence of bloat. New Zealand J. Agric. Res. 1994, 37, 535-545. [CrossRef]

30. Baert, J.; Vliegherf, A.D.; Hulle, S.V.; Waes, C.V.; Muylle, H.; Warda, M. Biomass yield and composition from semi-extensively cultivated perennial fodder grasses. Grassland-a European Resource? Proceedings of the 24th General Meeting of the European Grassland Federation. Available online: https:/pure.ilvo.be/portal/files/435292/ 3102.pdf (accessed on 7 February 2020).

31. Karsten, H.D.; MacAdam, J.W. Effect of drought on growth, carbohydrates, and soil water use by perennial ryegrass, tall fescue, and white clover. Crop Sci. 2001, 41, 156-166. [CrossRef]

32. Cougnon, M.; Deru, J.; Van Eekeren, N.; Baert, J.; Reheul, D. Root depth and biomass of tall fescue vs. perennial ryegrass. In Proceedings of the 17th Symposium of the European Grassland Federation, Akureyri, Iceland, 23-26 June 2013; Available online: http://www.europeangrassland.org/fileadmin/media/EGF2013.pdf (accessed on 26 November 2014).

33. Visscher, J.; Radersma, S.; Van Den Pol-Van Dasselaar, A. Innovations in Grazing Systems (In Dutch: Innovaties in Beweidingssystemen). 2011. Available online: http://edepot.wur.nl/202654 (accessed on 2 October 2012). 
34. Royal Dutch Weather Institute. Daily data of the Weather in The Netherlands. In Dutch: Daggegevens van het weer in Nederland. 2016. Available online: https://www.knmi.nl/nederland-nu/klimatologie/daggegevens (accessed on 2 January 2017).

35. Deru, J.; Van Eekeren, N.; De Wit, J.; De Boer, H. Effect of Grass Species and N-Fertilization Level on Production, Rooting and Mineral N in Autumn: Field Trial on Sandy Soil with Perennial Ryegrass, Cocksfoot and tall Fescue (In Dutch: Effect van Grassoort en N-Bemestingsniveau op Productie, Beworteling en N-Mineraal in de Herfst: Veldproef op Zandgrond met Engels Raaigras, Kropaar en Rietzwenkgras); Rapport 2011-017 LbD.; Louis Bolk Instituut: Driebergen, The Netherlands, 2011.

36. Lorentz, C.; Lal, R. The Depth Distribution of Soil Organic Carbon in Relation to Land Use and Management and The Potential of Carbon Sequestration in Subsoil Horizons; Carbon Management and Sequestration Center: Columbus, OH, USA, 2005; Available online: http://inread.usarb.md:8888/tinread/fulltext/lal/depth.pdf (accessed on 27 November 2014).

37. Hoogsteen, M.J.J.; Lantinga, E.A.; Bakker, E.J.; Groot, J.C.J.; Tittonell, P.A. Estimating soil organic carbon through loss on ignition: Effects of ignition conditions and structural water loss. Eur. J. Soil Sci. 2015, 66, 320-328. [CrossRef]

38. Van Eekeren, N.; Bos, M.; De Wit, J.; Keidel, H.; Bloem, J. Effect of individual grass species and grass species mixtures on soil quality as related to root biomass and grass yield. Appl. Soil Ecol. 2010, 45, 275-283. [CrossRef]

39. Carter, M.R.; Gregorich, E.G. Carbon and nitrogen storage by deep-rooted tall fescue (Lolium arundinaceum) in the surface and subsurface soil of a fine sandy loam in eastern Canada. Agric. Ecosyst. Environ. 2010, 136, 125-132. [CrossRef]

40. Gill, J.; Burcke, I.C.; Milchumas, D.G.; Laueenroth, W.K. Relationship between roots and soil organic matter pools in the shortgrass steppe of eastern Colorado. Ecosystems 1999, 2, 226-236.

41. Don, A.; Scholten, T.; Schulze, E.D. Conversion of cropland into grassland: Implications for soil organic-carbon stocks in two soils with different texture. J. Plant Nutr. Soil Sci. 2009, 172, 53-62. [CrossRef]

42. Johnston, A.E.; Poulton, P.R.; Coleman, K. Soil organic matter: Its importance in sustainable agriculture and carbon dioxide fluxes. Adv. Agron. 2009, 101,1-57.

43. Maillard, É.; Angers, D.A.; Chantigny, M.; Bittman, S.; Rochette, P.; Lévesque, G.; Hunt, D.; Parent L, É. Carbon accumulates in organo-mineral complexes after long-term liquid dairy manure application. Agric. Ecosyst. Environ. 2015, 202, 108-119. [CrossRef]

44. Soussana, J.F.; Allard, V.; Pilegaard, K.; Ambus, P.; Amman, C.; Campbell, C.; Valentini, R. Full accounting of the greenhouse gas $\left(\mathrm{CO}_{2}, \mathrm{~N}_{2} \mathrm{O}, \mathrm{CH}_{4}\right)$ budget of nine European grassland sites. Agric. Ecosyst. Environ. 2007, 121, 121-134. [CrossRef]

45. Soussana, J.F.; Tallec, T.; Blanfort, V. Mitigating the greenhouse gas balance of ruminant production systems through carbon sequestration in grasslands. Animal 2010, 4, 334-350. [CrossRef]

46. Ward, S.E.; Smart, S.M.; Quirk, H.; Tallowin JR, B.; Mortimer, S.R.; Shiel, R.S.; Wilby, A.; Bardgett, R.D. Legacy effects of grassland management on soil carbon to depth. Glob. Chang. Biol. 2016, 22, 2929-2938. [CrossRef]

47. Rijksinstituut voor Volksgezondheid en Milieu (RIVM, National Institute for Public Health and the Environment, The Netherlands). Agricultural Practices and Water Quality at Grassland Farms Registered for Derogation in 2014 (In Dutch: Landbouwpraktijk en waterkwaliteit op landbouwbedrijven aangemeld voor derogatie in 2014); National Institute for Public Health and the Environment: Bilthoven, The Netherlands, 2016.

48. De Haan, J.J.; van Geel, W.C.A. Manual on Soil and Fertilization (In Dutch: Handboek Bodem en Bemesting). 2019. Available online: https://www.handboekbodemenbemesting.nl/nl/handboekbodemenbemesting/ Handeling/Organische-stofbeheer/Samenstelling-en-werking-organische-meststoffen/Samenstellingorganische-meststoffen.htm (accessed on 20 July 2019).

49. Conijn, J.G.; Lesschen, J.P. Soil Organic Matter in the Netherlands: Quantification of Stocks and Flows in the Top Soil; PRI Report 619/Lterra Report 2663; Research Institute Praktijkonderzoek Plant \& Omgeving/Plant Research International, Wageningen UR (University \& Research centre): Wageningen, The Netherlands, 2015. 
50. Skinner, R.H.; Dell, C.J. Yield and soil carbon sequestration in grazed pastures sown with two or five forage species. Crop Sci. 2016, 56, 2035-2044. [CrossRef]

(C) 2020 by the authors. Licensee MDPI, Basel, Switzerland. This article is an open access article distributed under the terms and conditions of the Creative Commons Attribution (CC BY) license (http://creativecommons.org/licenses/by/4.0/). 